\title{
Assessing the Hindrances and Prospects of Women's Entrepreneurship Development: The Case of Hosaena Town, Hadya Zone, SNNP, Ethiopia
}

\author{
Ephrem Ahadu ${ }^{1}$, Ageze Chufamo ${ }^{1}$, Tsegaye Abie ${ }^{2}$ \\ ${ }^{1}$ Department of Civic and Ethical Studies, Wachemo University, Hosaena, Ethiopia \\ ${ }^{2}$ Department of English Language and Literature, Wachemo University, Hosaena, Ethiopia
}

Email address:

eph_ahadu2008@yahoo.com (E.Ahadu)

\section{To cite this article:}

Ephrem Ahadu, Ageze Chufamo, Tsegaye Abie. Assessing the Hindrances and Prospects of Women's Entrepreneurship Development: The Case of Hosaena Town, Hadya Zone, Snnp, Ethiopia. American Journal of Management Science and Engineering.

Vol. 5, No. 3, 2020, pp. 32-41. doi: 10.11648/j.ajmse.20200503.12

Received: June 7, 2020; Accepted: June 24, 2020; Published: August 17, 2020

\begin{abstract}
Women's entrepreneurship is considered to have a noteworthy part in economic development. The issue of women empowerment has been important for Governments and other non-governmental organizations. Both primary and secondary data was collected. The result of the study indicates that women entrepreneurs are exposed to various obstacles in the area of economy such as: limited access to loan and finance, difficulties in accessing markets, the lack of own land and inheritance, and difficulties in accessing raw materials. The main difficulties identified by women entrepreneurs in the area of legal and administrative functions in the survey are: high interest rates, high taxes, difficulties in getting a loan, insufficient support from Governmental and Financial institutions, and the lack of possibility to influence policy making. In relation to social and cultural factors, results from the survey are ambiguous. The government should create gender- neutral laws and policies to create a stimulating environment for potential women entrepreneurs. Therefore, government should offer different forms of support to women entrepreneurs such as: tax incentives and grants for starting a business. Additional effort should be directed to increase the quality of existing support to entrepreneurship development as well to designing new programs that would better alleviate the obstacles identified in this study.
\end{abstract}

Keywords: Entrepreneurship, Hindrance, Women, Development, Prospect, Assessing

\section{Introduction}

Entrepreneurship, the act of business ownership and business creation, is a relatively new concept in many developing and transitional economies. Entrepreneurship emerges from an individual's creative spirit into long-term business ownership, job creation, and economic security. Creating employment for Ethiopians is a major challenge; there are insufficient opportunities in the formal sector to absorb rural people and new entrants into the labor force. Consequently, many people have been forced into marginal activities in the informal sector as subsistence farmers, petty traders, and tiny handicraft producers with limited market scope. This conglomeration of informal and micro-enterprises is in need of significant upgrading if the Government of Ethiopia is to be successful in its efforts to eradicate poverty and to strengthen the private sector as a creator of employment and economic growth. Part of this challenge will be changing attitudes about work in the micro and small enterprises sector, and a revitalization of the "entrepreneurial spirit" in the country. Entrepreneurship can offer minority and disadvantaged groups and women a way to enter the economic main stream (minority self-employment). Training women to enable them to possess entrepreneurial knowledge and skill is of great importance.

According to (Central Statistical Authority, 2007) Ethiopian women constitute over half of the total population, which means huge potential to be utilized for socio-economic development of the country. In other words, half of the burden of the responsibility to discharge in the development process of the country lies on women, the gain from the 
resources of the country is expected to be shared between the two classes, and any measures taken to develop entrepreneurship should consider women's entrepreneurship. Needless to point out that Ethiopia is among the underdeveloped countries where the level of economy is unable to employ all the existing workforces and create job opportunities for them in the country. Therefore, it becomes very imperative to develop as many entrepreneurs as possible so that the question of unemployment may be solved. Therefore, the objective of this study is to explore the specific challenges that obstruct the development of women's entrepreneurship and their prospects in entrepreneurship sector in Ethiopia with especial reference to SNNPE, Hadiya zone, Hosaena town. The overall objective of this study is to assess the hindrances and prospects of women's entrepreneurship in Ethiopia with special emphasis at Hosaena town. In view of the overall objective, the study selected the following topics as specific objectives: Explaining the role of women's entrepreneurship in economic growth; Describing the situation of women's entrepreneurship in Ethiopia; Exploring conditions that foster women's entrepreneurship development; Analyzing motivating factors for women to enter into entrepreneurship; Exploring recommendations and suggestions to address existing problems to promote women's entrepreneurship development in the area under investigation.

Entrepreneurship in general and women's entrepreneurship in particular in developing countries like Ethiopia has not been given sufficient attention, and adequate policy measures have not been taken to promote it though there are certain progresses since recent years. In addition, various gender specific challenges that impede the development and promotion of women's entrepreneurship have not been studied as required in the study area. Therefore, this study might contribute to take appropriate pro-women's entrepreneurship policy measures by indicating some policy directions. Secondly, the researchers have hoped that any interested potential academicals and researchers who undertake similar studies may refer to the research. Because the researchers have assumed that the suggestions that would be forwarded for the problems will help to identify the challenges for women's entrepreneurship development, women entrepreneurs of the study area will, as community, be benefited.

\section{Review of Literature}

The term entrepreneur first appeared in the French language to refer to the persons who take risks. In the $16^{\text {th }} \mathrm{c}$, it was applied to persons engaged in military expeditions, and later it was extended to cover construction and other civil engineering activities [10]. According to Dawit and Dawit. (2005). in the late $19^{\text {th }}$ and early $20^{\text {th }}$ century, entrepreneurs were often viewed as managers and from an economic point of view.

The concept of entrepreneurship has been around for a very long time, and different writers have forwarded many definitions of it emphasizing its various aspects. As the writes describe the term from their own perspectives, no consensus has been reached to have precise and universally accepted single definition. Most economic, psychological and sociological research points to the fact that entrepreneurship is a process and not a static phenomenon. Entrepreneurship is more than just a mechanical economic factor. Entrepreneurship has to do with change and is commonly associated with choice-related issues. Existing definitions of entrepreneurship often relate to the functional role of entrepreneurs and include coordination, innovation, uncertainty bearing, capital supply, decision making, ownership and resource allocation [27].

In the view of $[3,12]$ and [2], entrepreneurship is regarded as one of the factors of productions: land, labor, capital and entrepreneurship in that land is the foundation Labor \& Capital are the pillars, and entrepreneurship holds everything together.

Existing definitions of entrepreneurship often relate to the functional role of entrepreneurs and include coordination, innovation, uncertainty bearing, capital supply, decision making, ownership and resource allocation. Indeed, three of the most frequently mentioned functional roles of entrepreneurs are associated with major schools of thought on entrepreneurship: Risk seeking-entrepreneur willing to take the risk associated with uncertainty. Innovativeness- the entrepreneur accelerating the generation, dissemination and application of innovative ideas. Opportunity seekingentrepreneur perceiving and seizing new profit opportunities [27]. In the same way, many studies review the role of entrepreneurship without focusing on male or female entrepreneurs and they agree in that entrepreneurship is a vital vehicle in the development process of a country's economy. In the works of [7] and [2], the most important contributions of entrepreneurship to the economy is stated as creation of jobs, development of better products and production methods, abolition of monopoly and enhancement of competition, increase per capita output and income, and generation of foreign currency. Entrepreneurship is the source of sustainable economic prosperity for nations, societies, regions, corporations, small firms, and individuals. The authors added that entrepreneurship is a vital source of new job creation and a source of a vast majority of new technology and products. It also plays a key role in providing effective and innovative solutions to environmental and social problems.

Women entrepreneurs as (Siddique, 2008) are defined as woman or group of women, who initiate, organize and operate a business or enterprise. Countries across the world are benefiting from female entrepreneurship. According to the WB compiled by [4], Women's entrepreneurship, in Ethiopian context, is just more than generating income; it is about working to build more prosperous country to lift the many millions of Ethiopia's people out of poverty. It is also about achieving economic freedom and women's empowerment. Still it is about liberation of women's gender roles to create a better future for women's generations to 
come. By contributing new ideas, technologies, and production methods, women's entrepreneurship can boost productivity growth across the economy, even spurring existing firms to raise their productivity. As the study of [7, 24] and [14] argue that in terms of sector of activity, women tend to pursue areas where they have gender-based skills and expertise, such as food processing, clothing, and hairdressing, and gender-biases in the technical training sector tend to confine them to these areas. Others work in the agricultural sector, selling milk, vegetables, charcoal, crops etc from roadside market stalls just taking the associated risks of road congestion and high number of traffic accidents.

According to Zwede and Associates, (2002), women are described as functioning within a male dominated, patriarchal, and tradition-oriented society where sociocultural dynamics within the domestic and social spheres determine the status of women and the differential participation of women and men in public spheres. This has had a significant impact on gender roles and relations. It affects women's ability to travel away from home, own larger animals, and even control their own independent income.

\section{Research Methodology}

To conduct this study, more of qualitative approach followed by quantitative one was followed. Quantitative approach employed to undertake numerical analysis and interpretation of results whereas qualitative approach used to carry out emergent design, thematic discourse analysis, to make deeper understanding and thicker description of the problem under investigation and to present a detailed view of the study. The target population for this study is women entrepreneurs who are the owners of micro and small enterprises in the town. Key informants from concerned government offices such as heads of the three sub-town's trade and industry offices, women, children's and youth affairs' offices, women's league offices and the like was also parts of target population from which sample selections has been done.

Both primary and secondary data was collected. Primary data was collected from women entrepreneurs who are the owners of micro and small enterprises in the town and from key informants of the concerned government offices. Secondary data gathered from different published and unpublished documents such as books, researches reports, websites etc.

In this study, multistage sampling was used to determine sample size. In the first stage, from Hadiya Zone, Hosaena town selected purposively because it has large number of target population (women entrepreneurs) engaged in various economic sectors. The town has three sub-towns: Sechduna, Addis ketema and Gofermeda, and the sub-towns are divided into eight kebeles. As the data gathered by Hosaena town administration's trade and industry office in January 2010 show there are 325 micro and small enterprises' cooperatives. The cooperatives are classified under two categories: "package" and "medebegna"-whose equivalent term in English may be regular. Package refers to those various cooperatives which receive different supports from government whereas medebegna refers to cooperatives that receive only credit support from government. Out of 325 cooperatives 197 are package and the remaining 128 are medebegna. The 325 cooperatives have 3077 members of whom 1716 are males and 1361 are females; an average of four females in each cooperative. The three sub-towns share the 325 cooperatives as shown in the following table:

Table 1. Selected sub-towns.

\begin{tabular}{lllll}
\hline \multirow{2}{*}{ Cooperatives } & Sub-towns & & & Gofermeda \\
\cline { 2 - 5 } & Sechduna & Addisketema & 82 & 197 \\
\hline Package & 62 & 53 & 41 & 128 \\
Medebegna & 51 & 36 & 123 & 325 \\
Total & 113 & 89 & & \\
\hline
\end{tabular}

For the case of convenience $10 \%$ of the 325 cooperatives, 33 cooperatives was selected. Therefore, $33 \times 4=132$ women is the sample size. That is 11 cooperatives (46 women) from Sechduna, 9 cooperatives (36 women) from Addisketema and 13 cooperatives (50 women) from Gofermeda- $10 \%$ from each are taken. In the kebele level, Sechduna sub-town has three kebeles (Betel, Arada and Sechduna), Addisketema has two kebeles (Meilamba and Lichamba) and Gofermeda has three kebeles (Heto, Bobicho and Jellonaramo). The three kebeles of Sechduna have beeen randomly selected women entrepreneurs of 15 , 15 , and 16 respectively. Similarly, the two kebeles of Addisketema have 18 women each; and the three Kebeles of Gofermeda have 16, 17 and 17 respectively. The sum of these will be 132. Note that both the established cooperatives and individual women entrepreneurs was selected randomly except for key informants who was selected in a purposive sampling way.

Quantitative data was analyzed using simple descriptive statistical methods such as tables, pie-charts, percentages, ratios etc. Statistical Package for Social Science (SPSS) software was used to enter the data into computer system. Qualitative data was analyzed by transcribing informant's ideas and views through narrations, descriptions and discussions to help capture aspects of the research that could not be done through the quantitative method and to triangulate research findings derived from the literature reviews and primary sources. 


\section{Findings}

\subsection{Profile of Women Entrepreneurs}

The data analysis based on answers by respondents, includes education level, age, marital status, and family size.

Q.1- What is your education level?

As data show, the majority of respondents, $45 \%$ have completed higher school education, and $17 \%$ of respondents have completed university studies and the rest $25 \%$ of respondents have completed elementary school.

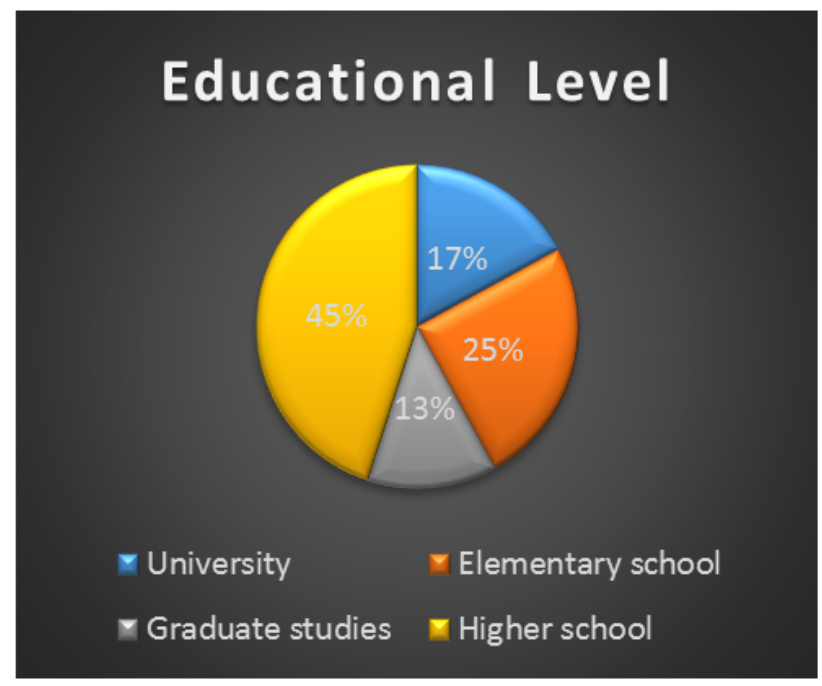

Figure 1. Education Level.

Q.2 -Your age is between a) $25-34$; b) $35-44$; c) $45-54$; d) 55-64

Respondents were asked to provide information on their current age.

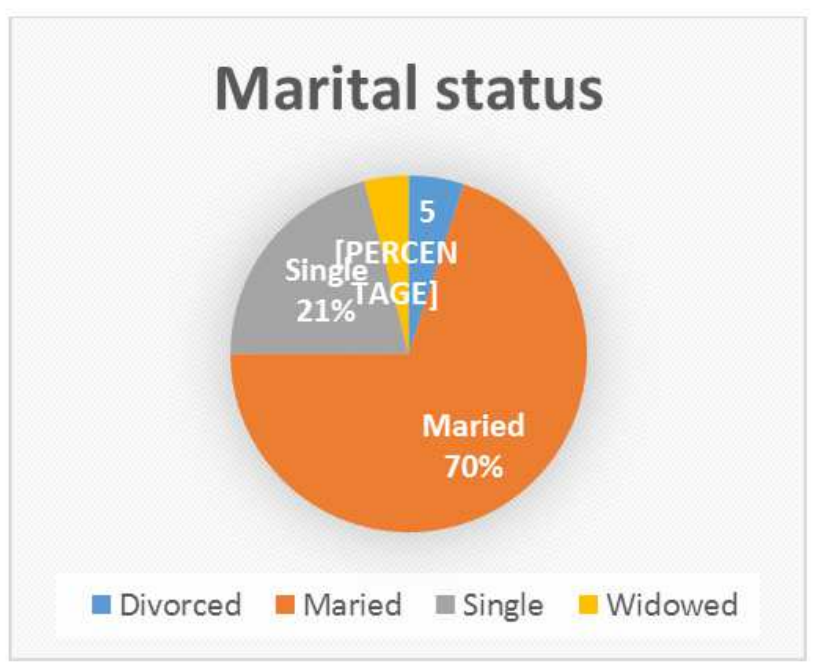

Figure 2. Marital Status.

The majority of women entrepreneurs responded that they are within the age category of 25-34 years old, while there are only $12 \%$ young women entrepreneurs between $34-44$ years old. This implies that young women are very keen to entrepreneur activities.

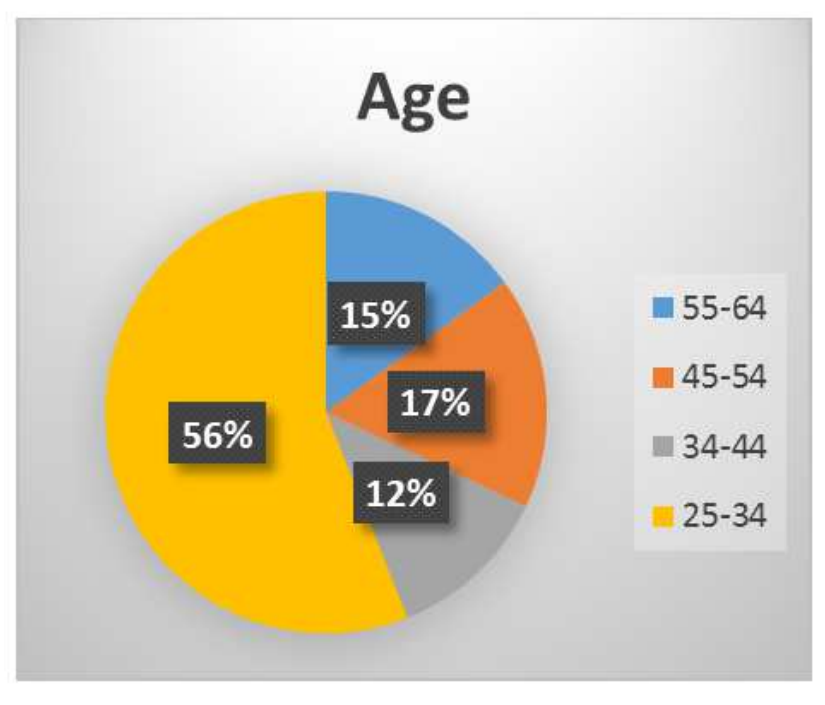

Figure 3. Age.

Q.3- What is your marital status?

In regard to marital status, respondents had to provide an answer from the four options provided for them; a) married; b) single; c) divorced; d) widowed

As shown in the figure above, the majority of women entrepreneurs' i.e $70 \%$ have declared that they are married.

\section{Family Size}

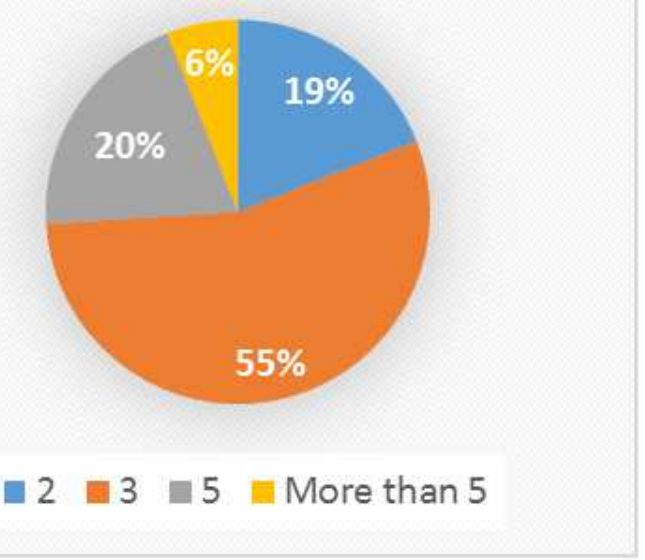

Figure 4. Family Size.

The majority of women entrepreneurs responded that they have a family size of 3 members. Relatively high is also the number of respondents who have more than 5 members, while family size of 2 members is quite rare.

\subsection{Characteristics of Women Entrepreneurs}

Even though there are common elements, there are a number of different characteristics that make women entrepreneurs from that of men entrepreneurs. The following figures show the characteristics of respondents by reasons to 
start own business, legal status of the business, the location of business, source of skills for starting the business, experience, number of employees, and family entrepreneurial history.

\subsection{Reasons to Start Own Business}

Q.5- Why did you start your own business?

Women entrepreneurs in the sample were asked to provide information about the reasons they started their own businesses and the results of the survey indicate that most of the respondents, 39\% started they own businesses for the reason to be self-employed and $17 \%$ of respondents have started their own business for the reason to fill a need they saw in the market for new product/service. There were $22 \%$ of respondents who started their own business because they did not have any other choice, while $6 \%$ of respondents inherited the business from family. Only $8 \%$ of respondents wanted to become financially independent and to make more money, whereas $2 \%$ of respondent started their own business because they were dissatisfied with their job.

Source of skills for running the business

Q.11- How did you get the skills for running your business?

In this question, respondents were asked to provide an answer from the five options provided for them; a) through trainings; b) from family; c) from friends; d) from past experience, and e) other.

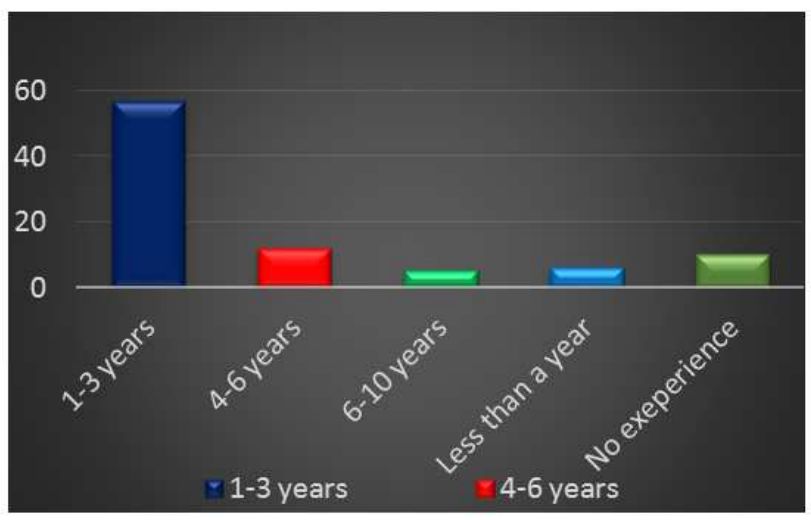

Figure 5. Experience.

As presented in the figure above, the majority of the respondents $62 \%$ acquired the necessary skills for running their business from past experience. Relatively high, $18 \%$ is the number of women entrepreneurs who acquired the skills for running a business from the family and training.

Q.13- What was your work experience before opening your business? Women entrepreneurs were asked to provide information about their working experience.

In the figure below are presented the answers in respect to the given question

The data reveals that majority of respondents had 1-3 years of work experience. There are relative high numbers of women entrepreneurs with no work experience.

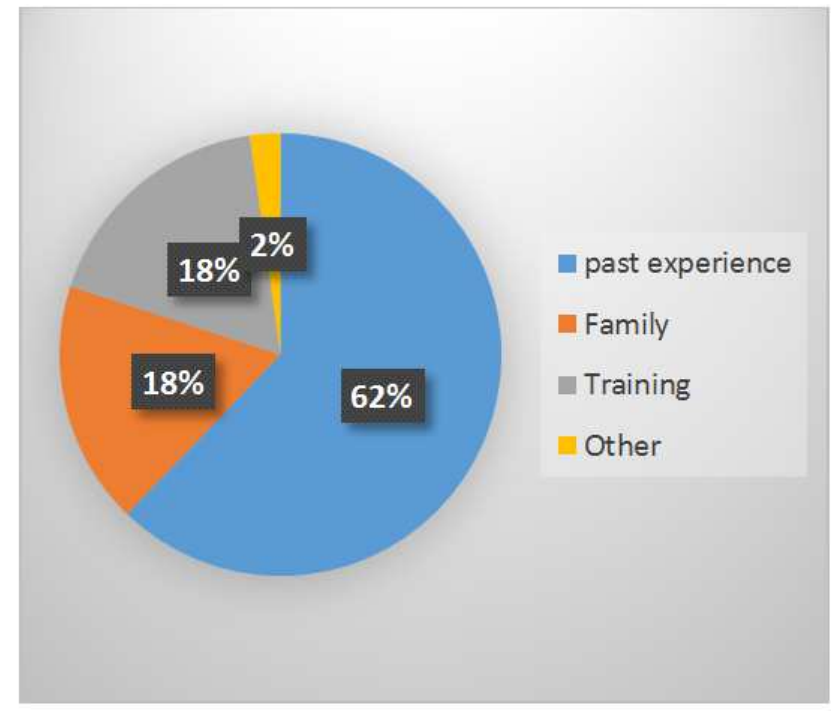

Figure 6. Source of skill.

Number of employees in the business

Q.14- What is the number of employees in your business?

Majority of respondents $34 \%$ have 4 employees in their business. There are moderate numbers of respondents $16 \%$ that employ 3 workers in their business. The number of women entrepreneurs that employ more than 20 employees is quite low.

Family entrepreneurial history

Q.15 - Is any of your family members an entrepreneur?

Women entrepreneurs were asked to provide information on whether any of their family members is an entrepreneur. The majority of women entrepreneurs declared that their husbands are entrepreneurs. Relatively high was also the number of women entrepreneurs whose fathers are entrepreneurs, while only $2 \%$ of women entrepreneurs responded that their mothers are entrepreneurs.

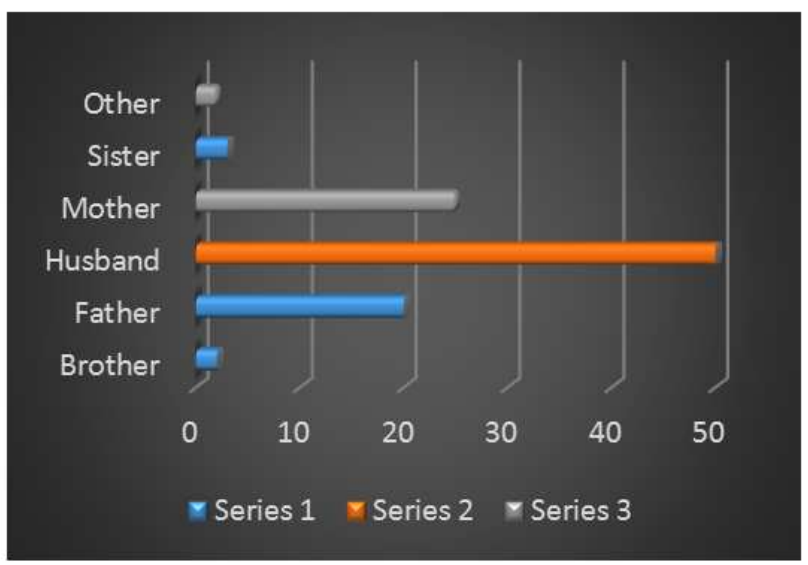

Figure 7. Family entrepreneural History.

Involvement of women entrepreneurs in business activities Q.6- In what type of business sector do you operate?

The figure below presents the involvement of women 
businesses by sectors.

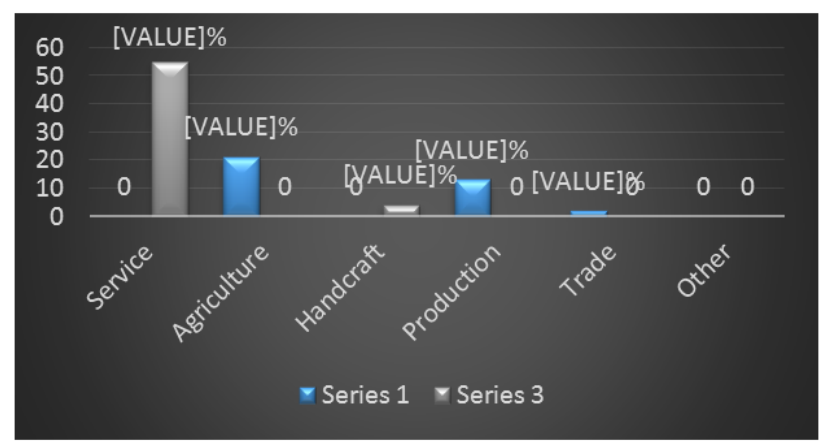

Figure 8. Involovement of women entreprenuers by sector.

The majority of women that is $55 \%$ entrepreneurs are involved in the service sector, whereas the number of women entrepreneurs involved in agriculture is $21 \%$. Only $4 \%$ of women entrepreneurs are involved in trade sector. To summarize, the main finding of this section in regard to the profile of women entrepreneurs studied are as follows: we found that the majority of women have secondary level of education, are aged between 25 and 34, married and their families are large, with 3 or more family members. Regarding other characteristics of women entrepreneurs studied on this research, the results show that women entrepreneurs start their business in order to be self-employed. This finding differs from those by Wube (2010) presented in section 2.4, who found that women in Dessie town- Ethiopia start their own businesses because they have no other alternatives. The most used legal form of business started by studied women entrepreneurs is cooperative. This differs from the findings of Wube (2010) who reported that the preferred legal form for women entrepreneurs in Dessie-Town, Ethiopia is a sole proprietorship. Besides, the majority of women entrepreneurs in this study have reported that the location of business is at the office or company premises. The results from the sample indicate that the respondents acquire the necessary skills for running their business from trainings, and have a working experience of 1-3 years. The majority of women entrepreneurs studied tend to employ 4 employees, and mostly female. Furthermore, high numbers of women entrepreneurs in this study reported that their husbands are entrepreneurs. In relation to the sector involvement, Yordanova and Davidkov (2009) as presented in section 2.4 found that women entrepreneurs in Bulgaria are mostly concentrated in trade sector. However, the results obtained for this study are different. We found that majority of women entrepreneurs studied are involved in service sector.

\section{Findings from the Survey on Factors Affecting the Performance and Success of Women Entrepreneurs}

\subsection{Economic Factors}

The results obtained from the statement: "I have access to sustainable loans and finance", shows that the majority of the respondents disagree with this statement. Whereas, only a small percentage of the respondents strongly agree that they have access to loan and finance. These results indicate that women entrepreneurs from the sample have difficulties in having access to loan and finance, which in turns can have a undesirable effect on the performance and further development of their businesses. In respect to the statement: "I have access to markets", the results presented below show that the majority of the respondents agree of having access to markets. Only $4 \%$ of the respondents disagree with this statement. The obtained data show that women entrepreneurs have access to markets. With regard to the third statement: 'I have access to different business trainings' the majority of the respondents strongly disagree on having attended various business training. The results indicate that women entrepreneurs from the sample are inactive in attending various business trainings. In view of the statement: 'I have access to information and networks', most of the respondents disagree on having access to information and networks. Contrary, a very small percentage agreed with the statement. The majority of women entrepreneurs studied declared that they have not access to information and networks. With the statement: "I possess managerial skills", the majority of respondents agreed. The results of the study show that respondents do possess managerial skills which enable them to lead their business and pretend for the future growth. The results for the statement: "I have experience in business ownership", show that more than $50 \%$ of the respondents agree with the statement. On the other hand, only a small percentage of the respondents disagree on having experience in business ownership.

The data indicate that women entrepreneurs in the sample had started their business with zero capital to establish their own businesses, since they did not inherit capital. With the statement: "I have access to necessary technology", the majority of respondents i.e more than $60 \%$ say that as they have no access. Answers indicate that women entrepreneurs have no access to technology they need for their businesses. The results for the statement: "I have access to inputs (raw materials)", show that only small percentages of respondents agree with the statement whereas majority of them are strongly disagree. These indicate that women entrepreneurs have problems in accessing the essential raw materials for their business purposes. In respect to the statement: "I am very optimistic for the future growth of my business in the next three years", the results show that more than half of the respondents are very optimistic. Obtained answers indicate that women entrepreneurs studied are very optimistic, in spite of obstacles they encounter. In order to evaluate the impact of economic factors influencing the success of women entrepreneurs, the mean and standard deviation are calculated separately for each question. The mean values show the level of agreement between respondents for each question. On the other side, the standard deviation values show how far individual 
responses deviate from the mean

Table 2. Analysis of Economic Factors

\begin{tabular}{lllll}
\hline Question & Economic factors & Frequency & Mean & Standard deviation \\
\hline Q1 & I have access to inputs (raw materials) & 179 & 2.22 & 1.0359 \\
Q2 & I have access to necessary technology & 179 & 3.6 & 0.7284 \\
Q3 & I have inherited capital from my family & 179 & 3.26 & 0.6943 \\
Q4 & I have my own land & 179 & 1.94 & 0.9775 \\
Q5 & I have experience in business ownership & 179 & 3.6 & 0.7284 \\
Q6 & I possess managerial skills & 179 & 2.22 & 1.0359 \\
Q7 & I have access to information and networks & 179 & 3.64 & 0.5980 \\
Q8 & I have access to different business trainings & 179 & 3.7 & 0.6776 \\
Q9 & I have access to markets & 179 & 3.82 & 0.5226 \\
Q10 & I have access to loan and finance & 179 & 3.38 & 0.7253 \\
\hline
\end{tabular}

The results on the impact of economic factors are similar with the literature on women's entrepreneurship. Prior research has indicated that access to finance, capital, networking, education, training and usage of technology are important determinants of performance and success of women entrepreneurs.

\subsection{Legal and Administrative Factors}

Table 3. Business Registration Procedures

\begin{tabular}{lllll}
\hline & Frequency & \% & Cumulative of the \# & Cumulative $\%$ \\
\hline Strongly disagree (1) & 179 & $100 \%$ & 36 & $20 \%$ \\
Disagree (2) & 179 & $100 \%$ & 100 & $56 \%$ \\
Neutral (3) & 179 & $100 \%$ & 7 & $4 \%$ \\
Agree (4) & 179 & $100 \%$ & 18 & $10 \%$ \\
Strongly agree (5) & 179 & $100 \%$ & 18 & $10 \%$ \\
\hline
\end{tabular}

This indicates that bureaucratic procedures not create as such difficulty for new business start-ups. The statement: "I can take a loan even without titled assets as collateral", shows that the majority of the respondents disagree in regard to this statement.

Regarding to loan provision, the result of the study indicates that women entrepreneurs, from the sample, are not able to get a loan due to the lack of collateral. In regard to the statement: "Interest rates charged by banks are very reasonable", results show that more than $90 \%$ of the respondents disagree and the interest rates charged by banks are high and not reasonable, thus, creating unfavorable conditions for women entrepreneurs to obtain a loan. In view of the statement: "I am beneficiary of Government grants",
With the statement: "My business is supported by Government bodies" the majority i.e $73 \%$ of respondents disagree; only a small percentage i.e $12 \%$ of the respondents declared that their businesses received government support and the rest are neutral. In regard to the statement: "The business registration procedures are very easy”, the majority of respondents disagree.
Table 4. Analysis of Legal and Administrative Factors.

\begin{tabular}{|c|c|c|c|c|}
\hline No. & Questions & Number of answers & Mean & Standard deviation \\
\hline 1 & Interest rates charged by banks are very reasonable & 179 & 1.44 & 0.7866 \\
\hline 2 & I can take a loan even without titled assets as a collateral & 179 & 3.24 & 0.8704 \\
\hline 3 & Women entrepreneurs are highly supported by banks and other financial institutions & 179 & 1.64 & 0.9848 \\
\hline 4 & am beneficiary of government grants & 179 & 1.54 & 0.8134 \\
\hline 5 & My business is supported by government bodies & 179 & 1.82 & 0.8497 \\
\hline
\end{tabular}

The obtained results on legal and administrative factors show that women entrepreneurs studied in this paper disagree with all statements and the difficulties they face are the following: obtaining a loan, bureaucratic bottleneck of registration of their business, high interest rates in banks, high taxes, obtaining government grants, support from banks and other institutions and participation in policy making. results show that majority of the respondents strongly disagree. In connection with the Government Grants, according to the results, most of women entrepreneurs are not supported by Governmental institutions through grants. In respect to the statement: "The taxes charged on my business are reasonable", results show that more than $75 \%$ of respondents strongly disagree with this statement. Taxes Charged to Businesses: women businesses are charged with high taxes. Results obtained on Legal and Administrative Factors show that women entrepreneurs encounter various difficulties in view of the legal and administrative perspective. In the table below the calculated mean and standard deviation for each question are presented in order to determine the relative impact of studied obstacles.

\subsection{Social and Cultural Factors}

Results on the statement: "Low-level risk taking attitude is a factor affecting women's decision to get into business", show that more than half of the respondents agree with the statement. The results imply that only $10 \%$ of the 
respondents strongly disagree that low-level risk taking attitude is factor affecting women's decision to get into business. In regard to the statement: "I have no cultural influences in operating my business", the results show that the majority of the respondents agree with the statement. On the other hand, only $5 \%$ of the respondents disagree with the statement. These indicate that women entrepreneurs studied feel that they are not culturally influenced.

To recap, the analysis of women entrepreneurs included in our sample do not encounter the difficulties due to the negative impact arriving from social and cultural factors. The majority of respondents took neutral position in answering to the statements, even in the case of the statement "I have enough time to spend with my family", or have felt a positive impact as in case of the declared family support to their businesses. These results are rather surprising, since in the literature, also surveyed in this paper, can be seen socio and cultural factors as those hindering either the entry or success of enterprises established by women entrepreneurs.

\section{Conclusions and Recommendations}

Women's entrepreneurship is considered to have a noteworthy part in economic development. The issue of women empowerment has been important for Governments and other non-governmental organizations. Moreover, lots of companies, communities and countries around the world are investing in women's entrepreneurship. As a result, women owned business has grown over time, representing a significant share of employment generation. Therefore, in developing entrepreneurship among women, sustained and coordinated efforts from all dimensions would make the way for the women moving into entrepreneurial activity, thus contributing to the social and economic development.

According to many researches related to women entrepreneurs, the most common factors affecting women entrepreneurs are: Access to loan and finance, lack of collateral, access to markets, access to education, access to networks, access to policy makers, work family interface, legal barriers and procedures, and lack of societal support. Women entrepreneurs studied in this paper face similar obstacles as found elsewhere in most developing countries in the perspective of economic, legal and administrative, and social and cultural factors. The aim of this study was evaluating, studying and presenting the major factors that affect the performance and success of women entrepreneurs in Hossaena town. The study also tried to address the characteristics of women entrepreneurs. In the view of the first research question on "Which the key factors affecting the performance and success of women entrepreneurs were", interviewed women entrepreneurs declared legal and administrative factors as to have the highest impact on the performance of their business. This occurs due to the lack of government support, access to policy makers, bureaucracies and the overall legal and administrative factors. In relation to the second research questionon "Which the business/sectors were in which women entrepreneurs are mostly involved", the majority of women entrepreneurs included in this study are engaged in service activities. Whereas, with respect to the third research question on "What the support given to women entrepreneurs in Hossaena was at present and how to improve it", it is found that support given to women entrepreneurs exists, but it is not satisfactory since only small percentage of women entrepreneurs have received grants from Governmental institutions. Besides, there is a lack of incentive based policies provided.

Therefore, based on the findings presented in this paper, women entrepreneurs are exposed to various obstacles in the area of economy such as: limited access to loan and finance, difficulties in accessing markets, the lack of own land and inheritance, and difficulties in accessing raw materials. The main difficulties identified by women entrepreneurs in the area of legal and administrative functions in the survey are: high interest rates, high taxes, difficulties in getting a loan, insufficient support from Governmental and Financial institutions, and the lack of possibility to influence policy making. In relation to social and cultural factors, results from the survey are ambiguous. However, as mentioned by FGD ${ }^{1}$, unfair competition, informal economy, and nonimplementation of the law on gender equalities, can be considered as factors that affect the performance and success of women entrepreneurs.

Starting a business is a huge challenge and requires a great deal of work and commitment. For women, sometimes the barriers can be harder to overcome. Even though a business can become a burden, on the other hand, it can also be rewarding. Starting own business creates a sense of independence, flexibility and financial freedom. It is important for women entrepreneurs to become self-confident on their entrepreneurial capabilities and empower themselves through education and trainings. If a potential woman entrepreneur has an idea, she should test it, disregarding the obstacles she might have to overcome after deciding to embark on the entrepreneurial journey. Besides this, women entrepreneurs should search for alternatives how to improve the performance and success of their businesses. For example, they should approach successful entrepreneurs to capitalize on their experience, not only in close community but also from different cities and regions to learn from best entrepreneurial practices.

Hossaena micro and small-scale enterprise should also collect and provide accurate statistics on women's entrepreneurship. This will be important for further research, for comparison, and understanding the economic impact of women entrepreneurs.

Since in this study legal and administrative environment are proven to be one of the major factors affecting women entrepreneurs' performance, the government should create gender- neutral laws and policies to create a stimulating environment for potential women entrepreneurs. Therefore, government should offer different forms of support to women entrepreneurs such as: tax incentives and grants for starting a

1 Focus Group Discussion 
business. Additional effort should be directed to increase the quality of existing support to entrepreneurship development as well to designing new programs that would better alleviate the obstacles identified in this study.

The lack of resources affects the growth of the businesses; thus, financial institutions should consider the possibilities of providing easier and affordable access to women businesses where Government guaranteed schemes could be an important instrument in this respect. State credit guaranteed schemes aim at diminishing the risk incurred by lenders and are mainly a reaction to lack of collaterally small firms. However, they also have the potential to reduce the costs of small-scale lending and to improve the information available on borrowers but can also improve the terms of a loan (more favorable lending conditions). The banking sector should explore the possibility to diversify their financial products in order to start offering equity financing, the type of financing that better suits to the development needs of new and small enterprises. In relation to further studies, it is recommended that more research is conducted to better understand women entrepreneurs. Through better understanding, better policies can be made to help and develop the full potential of women entrepreneurs.

\section{Acknowledgements}

This research is fully sponsored by Wachemo University and we would like to give credit for that.

\section{References}

[1] Alpha University College. (2005). Entrepreneurship: TVET, Unpublished teaching material. Addis Ababa.

[2] Bhatia and Batra. (2003). Entrepreneurship and Small Business Management. New Delhi: Ddeep and Deep Publications pvt.ltd.

[3] Central Statistical Authority. (2007). The 2007 population and housing census of Ethiopia. Adiss Ababa, Ethiopia.

[4] Chamlou, N. (2007). The Environment for Women's Entrepreneurship in the Middle East and North Africa Region: World Bank's report. Washington, DC: World Bank.

[5] Cursrud and Brannback. (2007). Entrepreneurship: GREENWOOD GUIDES TO BUSINESS AND ECONOMICS. London: Greenwood Publishing Group, Inc.

[6] DAMWAD. (2007). Women Entrepreneurship - A Nordic Perspective. Nordic Innovation Centre.

[7] Dawit and Dawit. (2005). Entrepreneurship: A challenging expedition to success. Adiss Ababa: Branna P. E.

[8] Desai, V. (1997). Dynamics of Entrepreneurial Development and Management. Mumbai: Himalia Publishing House, cited in Dawit and Dawit, 2005.

[9] Desta, S. (2010). Desk Review of Studies Conducted on Women Entrepreneurship in Ethhiopia. Adiss Ababa: Addis Ababa Chamber of Commerce.
[10] Gupta and Khanka. (2000). Entrepreneurship and Small Business Management (4th ed.). New Delhi, India: Sultan and Sons publishing pltd.

[11] Hailay, G. (2003). Entreprreneurship and Small Business Management. Mekelle: Ethio Central Printing.

[12] Hastings, P. G. (1974). Introduction to Business (2 ed.). USA: McGraw-Hill, Inc.

[13] Hayami and Godo. (2005). DEVELOPMENT ECONOMICS: From the Poverty to the Wealth of Nations. New York: Oxford University Press.

[14] Hisrich and Peters. (2002). Entrepreneurship (5 ed.). New Delhi: Tata McGraw-Hill Publishing Limited.

[15] Holt, D. H. (2003). Etrepreneurship: New Venture Creation. New Delhi: Prentice-Hall of India private limited.

[16] International Labour Organization (ILO). (2003). Ethiopian Women Entrepreneurs: Going for Growth. Geneva.

[17] Merwe and Lebakeng. (n. d.). AN EMPIRICAL INVESTIGATION OF WOMEN ENTREPRENEURSHIP IN LESOTHO. Retrieved Oct 20, 2011.

[18] Organization for Economic Co-operation and Development (OECD) (1998). Fostering Entrepreneurship. Paris: OECD, cited in United Nations (2005).

[19] Organization for Economic Co-operation and Development (OECD) (2002). Benchmarking Fostering Firms Creation and Entrepreneurship. Paris: OECD Directorate for Science, Technology and Industry, quoted in United Nations (2005).

[20] Schumpeter, J. (1934). The Theory of Economic Development. Oxford: Oxford University Press, cited in (Gupta and Khanka, 2000).

[21] Schwab et al. (2011). The Africa Competitiveness Report 2011 The Africa Competitiveness Report 2011: A report prepared by World Economic Forum, the World Bank and the African Development Bank. Geneva: World Economic Forum.

[22] Shefsky, L. E. (1994). Entrepreneurs are Made Not Born. USA: McGraw-Hill, Inc.

[23] Siddique, U. (2008). Prospects and Problems of Women Entrepreneurs: A Study of Dakha City: A dissertation for mastrs degree in developmnet studies, BRAC university. Dakha.

[24] Stevenson and St-Onge. (2005). Support for Growth-oriented Women Entrepreneurs in Ethiopia. Geneva: International Labour Office.

[25] Tambunan, T. (2009). Women entrepreneurship in Asian developing countries: Their development and main constraints. Journal of Development and Agricultural Economics, 38-40.

[26] Thomas et al. (2011). Innovation and Small Business (Vol. 1). Brychan Thomas, Christopher Miller and Lyndon Murphy \& Ventus publishing Aps.

[27] United Nations. (2005). ENTREPRENEURSHIP AND ECONOMIC DEVELOPMENT: THE EMPRETEC SHOWCASE. UNITED NATIONS CONFERENCE ON TRADE AND DEVELOPMENT (p. 3). Geneva: [web]URL: http://www.unctad.org/en/docs/webiteteb20043_en:df accessed date 09/11/2011. 
[28] Yeshiareg, D. (2007). PROMOTING WOMEN'S ECONOMIC EMPOWERMENT IN AFRICA [website] accssed date 04/11/2011.

[29] Zwede and Associates. (2002). Jobs, Gender and Small
Enterprises in Africa: Preliminary Report, Women Entrepreneurs in Ethiopia in association with SEED, International Labour Office, Geneva, October. Addis Ababa: ILO Office. 